\title{
José Carlos González Boixo (ed.), Tendencias de la narrativa mexicana actual, ed. Ibero- americana-Vervuert-Bonilla Artigas, Madrid, 2009, 277 pp.
}

Los estudios que se reúnen en este volumen han surgido en el marco de un Proyecto de Investigación patrocinado por el Ministerio de Educación y Ciencia de España. Lo conforman un total de nueve artículos que profundizan en las tendencias más representativas de la narrativa mexicana de los últimos años. El año 1968, se trata, tal y como advierte el editor, de una fecha que ha sido fijada por la crítica literaria con frecuencia como una fecha simbólica en el devenir de la literatura de este país, y particularmente en el género mencionado.

José Carlos González Boixo, como editor del libro, realiza la introducción y se detiene en la descripción de cuál ha sido la evolución de la narrativa mexicana entre 1968 y la generación de la década de los años setenta. Resume algunas tendencias significativas del período narrativo analizado y su contribución sirve de preámbulo al sumario de estudios contenidos en este libro. A continuación se reseñan las diversas aportaciones críticas.

Rosa María Díez Cobo, en su artículo "La reescritura de la historia en la narrativa mexicana contemporánea", afronta la temática histórica a finales de los años setenta en la narrativa mexicana. Desarrolla en una sección introductoria un sucinto pero exhaustivo repaso a los conceptos historiográficos que han tratado la reescritura de la historia, para posteriormente analizar someramente algunas de las características que singularizan y que permiten individualizar el fenómeno narrativo de la novela histórica contemporánea en el marco mexicano y, por extensión, latinoamericano. A continuación, y con la intención de esbozar los aspectos destacados en el marco de la novela histórica mexicana contemporánea, la autora selecciona tres relatos paradigmáticos por su integración crítica de historia y ficción y por su recurso a las diversas estrategias discursivas propias de la nueva novela histórica: Las obras son: $\mathrm{La}$ noche de Tlatelolco de Elena Poniatowska (1971), Terra Nostra de Carlos Fuentes (1975) y Cielos de la Tierra de Carmen Boullosa (1997).

Natalia Álvarez Méndez intenta demostrar en "La narrativa escrita por mujeres desde 1968 a la actualidad" que la teoría y crítica literarias feministas no han de asociarse a exclusiones o dogmatismos, pues la riqueza de los estudios de género radica en la revisión de anteriores cánones y en el reconocimiento de la pluralidad de voces y miradas femeninas que destacan en el ejercicio de la escritura. La autora sostiene que el discurso femenino no nace de un condicionamiento genético sino histórico y social, por lo cual no ha de atenderse a la idea de sexo aunque sí a la de género sumada a las circunstancias específicas vividas por las mujeres. De ahí que las autoras hispanoamericanas den lugar, con los personajes y las tramas que crean, a una ideología de género, muy contextualizada, que teje complejas redes de significaciones 
en las que el sexo, raza, posición social y situación política inciden en las nociones de individuo, sociedad y nación. Desde esta perspectiva se acerca a la narrativa femenina mexicana, relacionada en gran medida con el testimonio de marginación y con la reivindicación de libertad. Como colofón analiza la novela Como agua para chocolate de Laura Esquivel, en la que tras una serie de argumentos, Natalia Álvarez Méndez señala que hay un feminismo latente debajo de esa estructura superficial de folletín o novela rosa y de libro de recetas de cocina en el que se presenta la discriminación de la mujer en la sociedad.

Javier Ordiz Vázquez en “Incursiones en el reino de lo insólito. Lo fantástico, lo neofantástico y lo maravilloso en la narrativa contemporánea" lleva a cabo un sucinto repaso a las obras que en los últimos años se han escrito en las tendencias recogidas en el título, deteniéndose en una breve aclaración y demarcación de cada uno de los conceptos. Parte de los orígenes de lo fantástico en México, tomando como punto de partida el relato de Lanchitas de Jose María Roa Bárcena en 1878 hasta llegar a autores de la Generación de Medio Siglo como Juan José Arreola, Guadalupe Dueñas o Elena Garro. Dentro de las tendencias actuales de lo fantástico que se han cultivado en México en los últimos cuarenta años, el autor identifica tres manifestaciones de lo fantástico con sus respectivos autores:

. El fantástico «clásico»: Pacheco, Fuentes y Solares. El «relato de horror».

. Lo neofantástico: Tario y Aridjis. El realismo mágico.

- Alberto Chimal y otros narradores de lo maravilloso.

Tomás Regalado López, en su artículo “Del boom al crack: anotaciones críticas sobre la narrativa hispanoamericana del nuevo milenio", analiza el grupo del crack en el contexto de la narrativa hispanoamericana de principios del siglo XXI y para ello revisa la historia de dicho grupo desde sus inicios, con los encuentros de sus propios integrantes a finales de los ochenta, hasta la consideración del mismo dos décadas después, cuando ya se han afianzado con cierta proyección tanto dentro como fuera del mundo hispánico. El autor recoge una caracterización sobre el crack para poder entenderlo como grupo, generación o tendencia siempre en el marco de la tradición hispanoamericana en una asociación con la novela del boom y sobre todo respecto al cuestionamiento de las falsas continuaciones del realismo mágico que tan en boga se pusieron en los años setenta y ochenta. En último lugar Tomás Regalado López señala en su artículo los vínculos ente las novelas escritas por los integrantes del crack y los postulados teóricos que habían revelado tanto en el «Manifiesto Crack» de 1996 como en el libro posterior de Crack. Instrucciones de uso, del año 2004.

Francisca Noguerol Jiménez, con su artículo "Entre la sangre y el simulacro: últimas tendencias en la narrativa policial mexicana", incursiona en el relato de detectives, también denominado neopolicial y cultivado entre otros por Paco Ignacio Taibo II. De esta manera, la autora comienza su análisis tomando como punto de partida la narrativa policial mexicana anterior a 1968, lo que califica como el reinado del Whodunit. Posteriormente, en los años setenta tiene lugar la configuración de un nuevo canon, el llamado Hard Boiled, cuyo apogeo concluiría con la llegada del 
neopolicial, entre cuyos rasgos identificatorios propios Francisca Noguerol destaca la relegación del enigma a un segundo plano, la presencia de la ley y la sociedad como responsables de los crímenes, la primacía de los otros en la trama, así como las huellas del periodismo y la impronta de la realidad. La autora incide asimismo en la aparición de otra serie de características propias del género como son la descentralización de los escenarios, el hecho de que las tramas no se desarrollen únicamente en D.F. sino también en provincias y en la frontera, la huella de medios masivos de comunicación como pueden ser la música, el cine, la televisión o el cómic y la hibridación con otros formatos narrativos.

Nina Pluta en "El género seudocriminal. Inspiraciones policíacas en las novelas mexicanas del cambio de siglo" demuestra cómo la novela mexicana en este cambio de siglo continúa recibiendo la influencia del género criminal, tal y como podemos observar en numerosos relatos que se ven impregnados por esta tendencia a pesar de no pertenecer al género propiamente dicho. Son las novelas denominadas seudopoliciales y en las que Nina Pluta incluye como cultivadores a Sergio Pitol, Juan Villoro, Jorge Volpi, Ignacio Padilla y Guillermo Fadanelli. Son textos en los que encontramos diversas extensiones metafóricas del crimen, que acaba convirtiéndose en muchas ocasiones en destino, voluntad de un supremo hacedor, en un crimen fundacional histórico o en el acto transgresivo de la razón humana. En definitiva, el mal está presente en una gran parte de las novelas mexicanas y el esquema tradicional del género se muestra ineficaz para recoger nuevas inquietudes y necesidades de los tiempos actuales.

Imelda Martín Junquera, en su artículo “Ecocrítica, racismo medioambiental y renacimiento chicano", centra su atención en la literatura chicana que escriben los mexicanos del sudoeste de los Estados Unidos. Una literatura de denuncia en la que se manifiestan no sólo las costumbres, las tradiciones y los ecosistemas del otro lado de la frontera mexicana, sino, y sobre todo las condiciones de racismo medioambiental en las que viven y trabajan estos mexicano-americanos. En este contexto surgen conceptos como barrio frente a valle, lo que delimita las diferencias entre las poblaciones rurales o urbanas.

En último lugar, Kristine Vanden Berghe, con su artículo "Desde las montañas del sureste", completa un recorrido por las diversas tendencias de la narrativa mexicana al incluir un interesante análisis de la trascendencia y el valor literario de los textos del Subcomandante Marcos, cuya prosa ha sido muy apreciada por diferentes críticos y escritores mexicanos. Así, Kristine Vanden Berghe profundizará en aspectos significativos de los relatos de ficción partiendo del análisis de los protagonistas de los mismos: El Viejo Antonio, Don Durito de la Lacandona, Elías y otros muchos personajes que en opinión de Vanden Berghe son trasuntos del autor. Son relatos que, como podemos concluir, ocultan un discurso tan ideológico como cualquier discurso político, pero a pesar de ello es patente que, con el paso de los años y la evolución de sus textos, el autor se ha esforzado por evitar que se lean de esa manera.

Como conclusión, podemos decir que nos encontramos ante un volumen caracterizado por su pluralidad temática en la narrativa mexicana actual, que 
proporciona la posibilidad de una consulta independiente de los artículos, según la conveniencia y el interés de cada lector. Sea ésta o no la intención del editor, no cabe duda de que el hecho de contar con tantos puntos de vista distintos nos da una idea de la enorme riqueza que encierra la temática propuesta y constituye, al mismo tiempo, uno de los mayores atractivos de la obra. La mencionada variedad se complementa con una lectura rápida y amena, por lo que la persona que se acerque a sus páginas recibirá una panorámica general del tema diversa y enriquecedora.

Siridia Fuertes Trigal 